efficacy of polypropylene mesh and jejunal graft for the repair of abdominal wall defect in dogs // Journal of Animal and Plant Sciences, 2008, Vol. 18. No. 2-3, P. 67- 71 .

Катков Николай Васильевич, канд. вет. наук, доцент кафедры «Морфология, патология животных и биология», Саратовский государственный аграрный университет имени Н. И. Вавилова. Россия.

410005, г. Саратов, ул. Соколовая, 335.

Тел.: (8452) 69-25-32.

Ключевые слова: брюшная стенка; кошка; морфометрия; устройство для сближения краев раны.

\title{
THE INFLUENCE OF SEGMENTAL PROFILE OF THE ABDOMINAL WALL OF A CAT ON THE WOUND EDGES' INSTRUMENTAL BRINGING TOGETHER OF DIFFERENT ORIGIN
}

Katkov Nicolaj Vasilyevich, Candidate of Veterinary Sciences, Associate Professor of the chair "Morphology, Pathology of Animals and Biology", Saratov State Agrarian University named after N.I. Vavilov. Russia.

Keywords: abdominal wall; cat; morphometry; the device for bringing together wound edges.

In the modeling of the ratio of plots of the abdominal wall with the device for the convergence of the edges of the wound we are determined the thickness of the layers of tissues. To reduce the risk of injury during fixation of tissues 11:41 AM they were determined limits of the depth of the spokes arrangement on the basis of measurement wound. Introduction spokes of the device near the wound was optimal. This result is achieved using the device, which is provided with a mechanism for automatically adjusting the position of spokes, a pointed part which is brought to the site on the border of the sidewall and bottom of the wound. of subcutaneous and internal fat of pigs of large white breed of different origin. It is noted that qualitative indicators of adipose tissue of pigs of large white breed of different origin had significant differences. For crossed young boars bred from import ones (in comparison with bred from Russian) in the subcutaneous spinal fat and internal fat they are marked high content of moisture and protein, and low content of dry matter and fat. Besides their melting point and density of subcutaneous spinal speck is below by 16.0 and $3.1 \%$, and the acid and iodine number is higher by 14.9 and $9.5 \%$. САНКТ-ПЕТЕРБУРГА

\author{
КОВЯЗИН Василий Фёдорович, Санкт-Петербургский государственный лесотехни- \\ ческий университет имени С.М. Кирова.
}

ФАМ Тхи Куинь, Санкт-Петербургский государственный лесотехнический университет имени С.М. Кирова.

КАН Ким Хынг, Санкт-Петербургский государственный лесотехнический университет имени С.М. Кирова

Приведены результаты многолетних наблюдений за почвенно-грунтовыми условиями парка «Сосновка», который расположен в Выборгском районе Санкт-Петербурга. Первоначально в составе насаждений преобладала сосна, но в связи с изменением почвенно-грунтовых условий произошла смена на мелколиственные породы. Изучены основные факторы, определяющие почвенно-грунтовые условия: уровень грунтовых вод, морфология и гранулометрический состав почвы. Установлено, что уровень грунтовых вод коррелирует с абсолютной отметкой метности относительно уровня Балтийского моря. Грунтовые воды определяют морфологическое строение почвы и ее гранулометрический состав.

$\Pi$ арк «Сосновка» находится в Выборгском районе Санкт-Петербурга. Площадь его составляет 302,07 га [1, 6], ограничен проспектами: Северным, Тихорецким, Светлановским и Тореза, а также улицей Есенина (рис. 1). Уникальность и ценность парка заключается в том, что под его создание в 1923 г. был отведен лесной массив, представленный чистым сосновым древостоем, в котором сплошными и выборочными рубками велась заготовка древесины. В то время в городских насаждениях совершенно отсутствовала сосна. Это и послужило причиной создания парка, ему придали особое санитарно-гигиеническое значение, так как сосновый лес является 
конденсатором чистого, здорового, озонированного воздуха [7, 9].

Северо-восточные окрестности СанктПетербурга, где расположен парк «Сосновка», представляют собой гряду, которая возвышается почти на 46 м над уровнем моря у Поклонной горы, тянется в юго-восточном направлении, постепенно понижаясь. С обеих сторон гряда ограничена террасовыми уступами. Самая высокая точка парка 36,73 м над уровнем моря, а самая низкая, восточная сторона, - 24,94 м [3, 5].

Возвышенная часть парка волнистая (древние береговые валы), сложена осадками раннеанцилового озера - «желтыми», средне- и крупнозернистыми, всегда почти хрящеватыми песками с прослойками гальки и валунчиков. Эти пески прослеживаются до уровня грунтовых вод. Подпочвой служит голубовато-сизоватая ленточная глина.

В связи с рельефом местности водный режим является главным фактором почвообразования в парке, особенно грунтовые воды первого от поверхности земли постоянного водоносного горизонта. Они образовались за счет насыщения земли атмосферными осадками, водами рек и озер, притоком поверхностных вод.

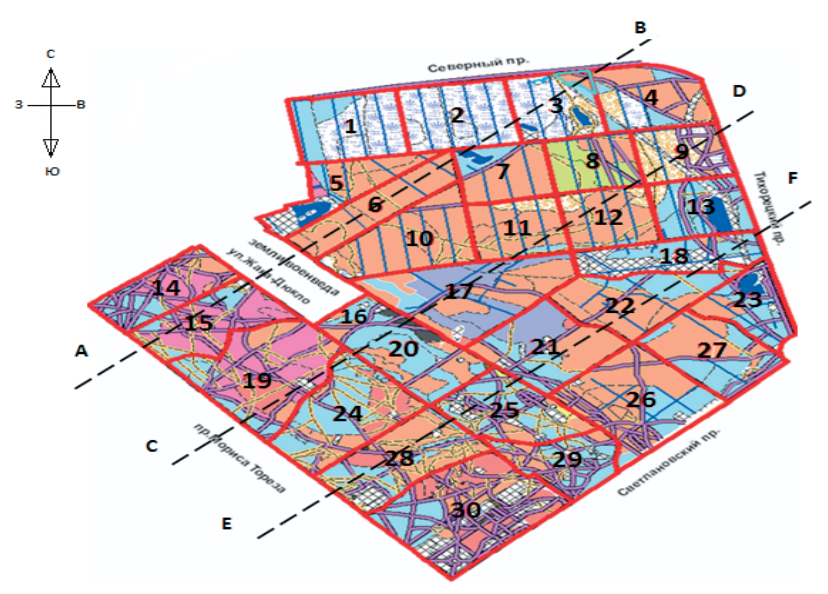

Рис. 1. Карта парка «Сосновка»

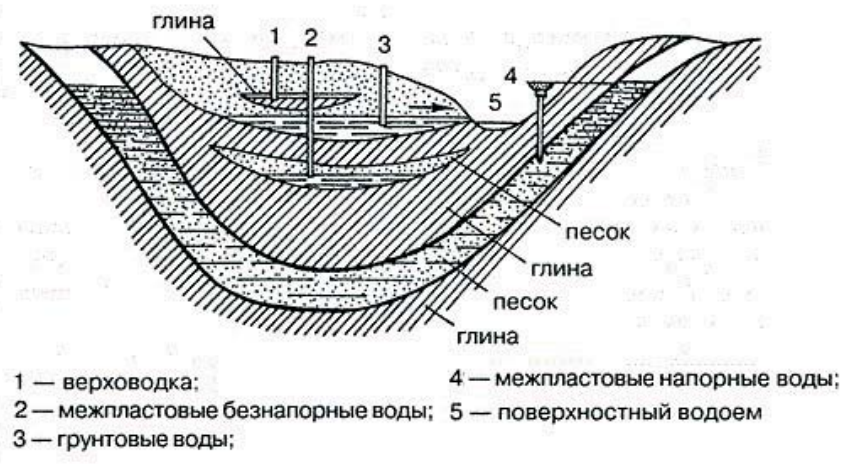

Рис. 2. Схема залегания грунтовых вод
1 - верховодка:

3-грунтовые воды;
Методика исследований. Уровень грунтовых вод (УГВ) представляет собой рубеж под землей, ниже которого находится водоносный слой. Осадки в виде дождя или снега попадают под землю и спускаются до УГВ в том месте, где жидкость останавливается и располагается предел заполнения водой почвы (рис. 2) [2].

УГВ определяли осенью, когда в СанктПетербурге выпадает наибольшее количество осадков. Делали скважину глубиной около 1 м садовым буром. Затем наблюдали некоторое время. Если вода в скважине появлялась, значит УГВ высокий. Если дно скважины оставалось сухим, то грунтовые воды залегают глубоко [4].

После выбора места для закладки почвенного разреза и его привязки к местности на поверхности почвы намечали контур в виде прямоугольника шириной 60-70 см и длиной 150-200 см. При описании почвенного профиля переднюю стенку разреза выравнивали и освежали, чтобы получить естественный излом почвы. Для этого к выровненной поверхности передней стенки прикладывали под прямым углом лопату или нож и слегка вдавливали в почву (на 1-3 см), затем отдергивали на себя. При этом от передней стенки разреза отваливался тонкий слой почвы, обнажая ее поверхность с естественным сложением. Так освежали половину стенки сверху донизу, где более четко выделись генетические горизонты, окраска почвы, ее тональность, структура, характер новообразований. Затем к лицевой стенке прикрепляли сверху вниз с помощью булавки измерительную ленту и определяли мощность горизонтов, глубину разреза, уровень залегания грунтовых вод. Морфологические признаки почв описывали после выделения генетических горизонтов. Описание почвы проводили в следующем порядке: название генетического горизонта, его буквенное обозначение, цвет и окраска, влажность, сложение, структура, гранулометрический состав, порозность, консистенция (твердость, пластичность, липкость, текучесть), биологические новообразования (корни травянистых растений и деревьев, ходы червей, черви, насекомые и т.д.), включения и обломки горных пород, переходные границы между генетическими горизонтами [8].

По такой схеме характеризовались все выделенные генетические горизонты. По 
описаниям приводили полное название почвы.

Результаты исследований. Измерение грунтовых вод в скважинах позволило нанести 3 профиля расположения их (см. рис. 1) по линиям, обозначенным на плане буквами A-B, C-D и E-F [3]. В возвышенной части парка «Сосновка» грунтовые воды доходят до 6 м (рис. 3). Они большей частью лежат на глубине 3,5-5 м по профилю E-F, в местах перегиба летом происходит пересыхание почвы.

С повышением местности в сторону Поклонной горы грунтовые воды приближаются к поверхности (южный угол парка - до 6 м, северо-западный угол - до 1,5 м), рис. 4.

В пониженной части парка грунтовые воды близки к дневной поверхности (рис. 5). Они залегают на сизо-голубоватой глине. При глубоком стоянии грунтовых вод, которое наблюдается на возвышенной Соснов-

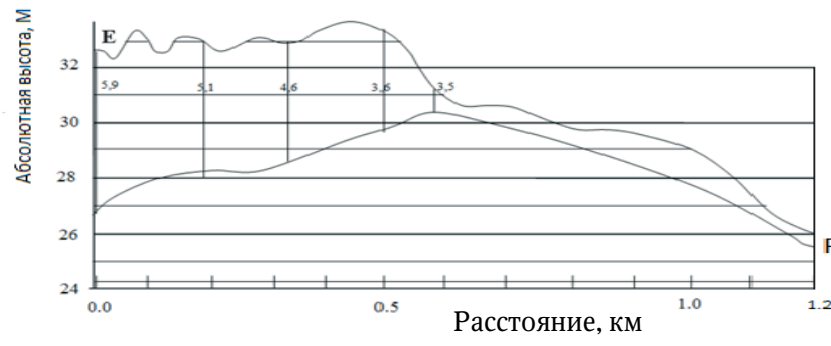

Рис. 3. Продольный профиль по линии Е-F

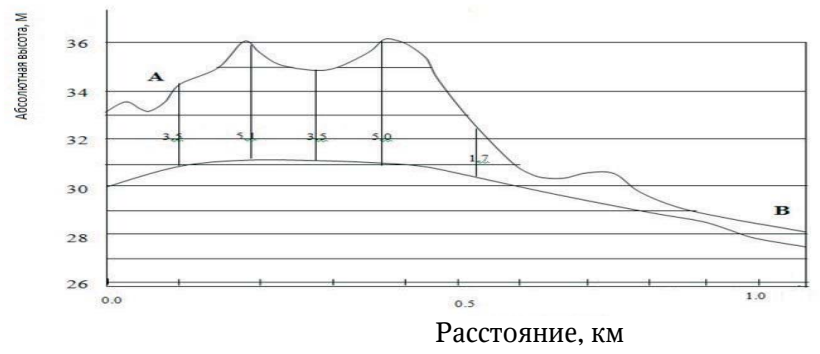

Рис. 4. Продольный профиль по линии А-В

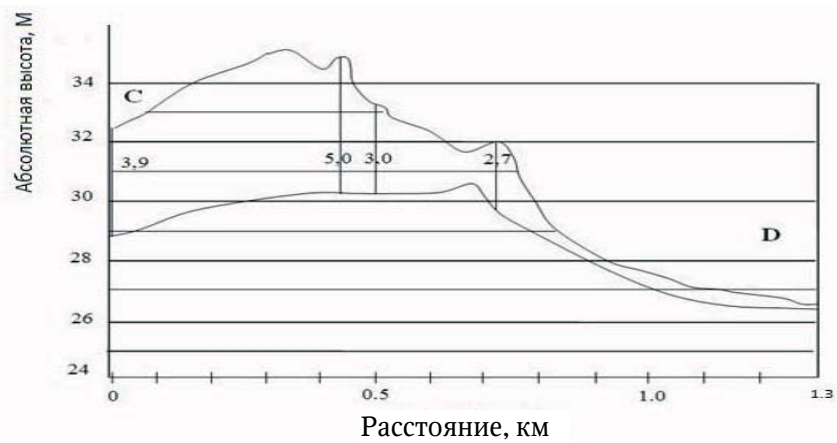

Рис. 5. Продольный профиль по линии C-D ской гряде, они не имеют почти никакого значения для растительности. Способность песков удерживать влагу здесь ничтожна, в результате грубого гранулометрического состава. Поэтому обеспечение растительности водой происходит за счет иного источника влаги.

Распределение влажности по вертикали подчинено определенной закономерности. Достигая максимума в самых верхних обогащенных гумусом и мелкоземом горизонтах, она резко падает ниже их, что особенно проявляется после дождей. Более или менее заметное увеличение влажности отмечается на глубине 0,5-1 м. Однако самая значительная величина влажности здесь не превосходит $28 \%$, что соответствует наибольшей влагоемкости песков парка «Сосновка».

Оптимальная влажность равняется 14$15 \%$, что составляет около половины наибольшей влагоемкости песков Сосновской гряды (около 28 \%). Там, где грунтовые воды приближаются к поверхности хотя бы до 2,5-3 м, мы имеем III, а при большей влажности даже IV классы бонитета сосновых насаждений.

Возвышенная гряда имеет почвы хрящевато-песчаные дерновые, горизонт $\mathrm{A}_{2}$ почти не выражен (табл. 1). Рассматриваемый разрез (см. табл. 1) почти одинаков для всей возвышенной части парка «Сосновка». На склоне гряды, при переходе в пониженную часть парка, условия увлажнения улучшаются. Ортштейновый горизонт (В) принимает ржавую окраску. Горизонт $\mathrm{A}_{2}$ доходит до 7 см.

Спускаясь в низину, у подошвы террасового уступа благодаря высачиванию из-под него грунтовых вод наблюдается развитие торфяных болот. В одних случаях застаиванию воды и образованию торфяников способствуют продолговатые котловинные западины (торф до 1 м мощностью). В других случаях болотца образуются даже при непрерывном снижении рельефа (табл. 2). Далее по профилю образуется «зона» подзолистых почв (табл. 3,4$)$.

После полосы болот снова отмечаем торфянисто-подзолистые почвы, но уже более мелкие. Голубая глина залегает на глубине не более 70 см от поверхности. Грунтовые воды поднимаются весной и осенью до 10-30 см от поверхности. Ортштейновый горизонт (В) разделяется на два: сверху темно-буро- 


\section{Почвенный разрез в квартале 19 парка «Сосновка»}

\begin{tabular}{|c|c|l|}
\hline Глубина, см & Горизонт & \multicolumn{1}{|c|}{ Характеристика почвенных горизонтов } \\
\hline $0-2$ & $\mathrm{~A}_{0}$ & Лесная подстилка \\
\hline $2-3$ & $\mathrm{~A}_{1}+\mathrm{A}_{2}$ & $\begin{array}{l}\text { Аморфная перегнойная масса темного (почти черного) цвета с } \\
\text { разбросанными молочно-белыми песчинками полевого шпата и } \\
\text { розовыми песчинками кварца, группирующимися местами в беле- } \\
\text { соватые прослоеки }\end{array}$ \\
\hline $3-15$ & $\mathrm{~B}_{1}$ & $\begin{array}{l}\text { Коричневый средний и крупнозернистый песок. Песчинки кварца и } \\
\text { ортоклаза окутаны налетом коричневого вещества; при высыхании } \\
\text { пылит, постепенно светлея книзу }\end{array}$ \\
\hline $15-30$ & $\mathrm{~B}_{2}$ & $\begin{array}{l}\text { Охристый песок такого же состава, но с примесью гальки. При вы- } \\
\text { сыхании пылит }\end{array}$ \\
\hline$>30$ & С & $\begin{array}{l}\text { Песок с гравием, галькой и валунчиками. В верхней части при вы- } \\
\text { сыхании несколько пачкает пальцы }\end{array}$ \\
\hline
\end{tabular}

Таблица 2

Почвенный разрез в квартале 22 парка «Сосновка»

\begin{tabular}{|c|c|l|}
\hline Глубина, см & Горизонт & \multicolumn{1}{|c|}{ Характеристика почвенных горизонтов } \\
\hline $0-3$ & $\mathrm{~A}_{0}$ & Светло-бурый рыхлый войлок \\
\hline $3-10$ & $\mathrm{~A}_{1}$ & $\begin{array}{l}\text { Перегнойный горизонт почти черного цвета, плотный; много белесых } \\
\text { песчинок }\end{array}$ \\
\hline $10-20$ & $\mathrm{~A}_{2}$ & Мелкозернистый буровато-белесый песок \\
\hline $20-50$ & $\mathrm{~B}_{1}$ & $\begin{array}{l}\text { Песок темно-охристого цвета. На границе с } \mathrm{A}_{2}-\text { темно-ржавая полоса 2- } \\
\text { см мощности. С 33 см песок принимает палевый, а с 40 см - оранжево- } \\
\text { ржавый оттенки }\end{array}$ \\
\hline $50-62$ & $\mathrm{~B}_{2}$ & \begin{tabular}{l} 
Ортштейн плотный, ржаво-красного цвета \\
\hline $62-90$
\end{tabular} \\
\hline С & $\begin{array}{l}\text { Серовато-палевый среднезернистый песок, с } 90 \text { см зеленовато-голубая } \\
\text { глина }\end{array}$ \\
\hline
\end{tabular}

Почвенный разрез в квартале 9 парка «Сосновка»

\begin{tabular}{|c|c|l|}
\hline Глубина, см & Горизонт & \multicolumn{1}{|c|}{ Характеристика почвенных горизонтов } \\
\hline $0-5$ & $\mathrm{~A}_{0}$ & $\begin{array}{l}\text { Темно-бурый плотный, почти разложившийся торф из стеблей ку- } \\
\text { кушкина льна }\end{array}$ \\
\hline $5-32$ & А & $\begin{array}{l}\text { Мелкий песок грязно-белесого цвета со слабым сизоватым оттенком. } \\
\text { Особенно затемнен сверху потеками и пятнами гумуса }\end{array}$ \\
\hline $32-60$ & В & $\begin{array}{l}\text { Темно-охристый песок с ржавыми и желтоватыми пятнами. Книзу } \\
\text { гранулометрический состав несколько грубеет. Появляются валунчи- } \\
\text { ки и разложившийся (гнездами) гранит, который резко переходит в } \\
\text { глину }\end{array}$ \\
\hline$>60$ & С & $\begin{array}{l}\text { Сизовато-охристого цвета слой почвы. Сверху глина пористая и по- } \\
\text { крыта пятнами и примазками по входам корней, здесь же имеются } \\
\text { галька, песок }\end{array}$ \\
\hline
\end{tabular}


го (гумус), глубже коричнево-желтого цвета. Сильное развитие микрорельефа создает здесь весьма пеструю картину почвенного разреза.

Дальше почвы сменяются на торфянистоподзолисто-глеевые. Грунтовые воды подходят почти к поверхности. Если они большую часть года держатся на поверхности, то мы имеем торфянисто-глеевые почвы. В табл. 5 дано описание торфянисто-подзолисто-глеевых (квартал 4) и торфянисто-глеевых почв (квартал 9).

Наиболее низкие места, вдоль северной границы парка, занимают болотные торфяные почвы, примыкающие к обширному торфяному болоту. Мощность торфа доходит до 1 м. Грунтовые воды держатся на поверхности в течение целого года, пересыхая лишь в сильную жару. Описание почвенного разреза в квартале 4 показало, что по вертикали до глубины 50-60 см, а иногда и больше, наблюдается заметное увеличение крупных фракций, особенно хряща. При дальнейшем углублении увеличивается количест- во мелкозернистых элементов. Количество фракций мельче 0,05 мм по мере углубления снижается. С глубины 50-60 см они исчезают совсем (табл. 6).

Под влиянием процессов почвообразования и выветривания железистые соединения, содержащиеся в минералах местного наноса, окислялись, и железо «проявлялось», выделившись на поверхности в виде рыжеватого налета.

Выводы. В парке «Сосновка» отмечено ухудшение почвенно-грунтовых условий, необходимых для роста сосновых насаждений. Это связано с рельефом местности и застройкой городской территории вокруг границы рекреационной зоны.

Водный режим территорий является главным фактором в почвообразовании. Исследование уровня грунтовых вод по трем направлениям парка показало, что их глубина зависит от рельефа местности и меняется от 4,5 до 6 м. Грунтовые воды залегают на сизоголубоватой глине, а водоподнимающая способность песков в этих условиях ничтожна,

Почвенный разрез в квартале 4 парка «Сосовка»

\begin{tabular}{|c|c|c|}
\hline Глубина, см & Горизонт & Характеристика почвенных горизонтов \\
\hline $0-9$ & $\mathrm{~A}_{0}$ & Бурая подушка из мертвых стеблей кукушкина льна и пр. \\
\hline $9-24$ & $\mathrm{~A}_{1}$ & Темно-бурый разложившийся торф. Сверху слой угля \\
\hline $24-46$ & $\mathrm{~A}_{2}$ & $\begin{array}{l}\text { Мелкий глинистый песок, окрашенный в слабо-кофейный тон, с верти- } \\
\text { кальными черточками полуразложившихся корней. Постепенно пере- } \\
\text { ходит в следующий горизонт }\end{array}$ \\
\hline $46-66$ & $\mathrm{~B}_{1}$ & $\begin{array}{l}\text { Белесовато-сизоватого цвета, того же гранулометрического состава. Мас- } \\
\text { са мелких блесток слюды }\end{array}$ \\
\hline $66-70$ & $\mathrm{~B}_{2}$ & $\begin{array}{l}\text { Среднезернистый песок с отдельными крупинками ортоклаза до } 3 \text { мм, } \\
\text { желтоватого цвета. В нем имеются валунчики до 16-20 см, изредка галь- } \\
\text { ка }\end{array}$ \\
\hline$>70$ & $\mathrm{C}$ & $\begin{array}{l}\text { Синевато-сизая глина с ржавыми пятнами, с включением песка, гравия и } \\
\text { обломков разложившего гранита (гнездами) }\end{array}$ \\
\hline
\end{tabular}

Гранулометрический состав торфянистых почв в парке «Сосновка», \%

\begin{tabular}{|c|c|c|c|c|c|}
\hline \multirow{2}{*}{$\begin{array}{c}\text { Место } \\
\text { нахождения } \\
\text { разреза }\end{array}$} & \multicolumn{5}{|c|}{ Гранулометрический состав почвы, мм } \\
\cline { 2 - 6 } & $3,0-1,0$ & $1,0-0,25$ & $0,25-0,05$ & $0,05-0,01$ & $<0,01$ \\
\hline Квартал 4 & 1,0 & 51,8 & 44,6 & 1,9 & 0,7 \\
\hline Квартал 9 & - & 5,0 & 75,8 & 12,4 & 8,8 \\
\hline
\end{tabular}


Гранулометрический состав торфянистых почв в зависимости от мощности горизонтов, \%

\begin{tabular}{|c|c|c|c|}
\hline \multirow{2}{*}{ Горизонт } & \multirow{2}{*}{ Глубина, см } & \multicolumn{2}{|c|}{ Размер частиц, мм } \\
\cline { 3 - 4 } & & $0,05-0,01$ & $0,01-0,001$ \\
\hline $\mathrm{B}_{1}$ & - & 4,5 & 4,1 \\
\hline $\mathrm{B}_{2}$ & - & 4,0 & 1,1 \\
\hline $40-50$ & $40-50$ & 2,0 & Нет \\
\hline Глубже & Глубже 50 & Нет \\
\hline
\end{tabular}

потому питание растительности происходит за счет иного источника влаги.

В парке преобладают хрящевато-песчаные дерново-подзолистые почвы, которые в условиях высокого стояния грунтовых вод сменяются торфянисто-глеевыми. По вертикали почвенного профиля до 60 см отмечается увеличение крупных фракций горной породы.

Результаты исследований переданы администрации парка.

\section{СПИСОК ЛИТЕРАТУРЫ}

1. Вихарев Г.С., Мезенко А.Н., Барбакадзе Б.Я. Зеленые насаждения // Охрана окружающей среды, природопользование и обеспечение экологической безопасности в Санкт-Петербурге в 1980-1999 годы. - СПб., 2000. - С. 289- 293.

2. Всё о бурении. Как определить уровень грунтовых вод. - Режим доступа: http://vseoburenii.ru/usloviya/opredelenie-urovnya-gruntovyxvod.html (дата обращения 26.11.2016).

3. Иванов Л.А., Кобранов Н.П., Сукачев В.Н. Природа и хозяйство учебно-опытных лесничеств Ленинградского лесного института: сб. статей. - Л., 1928. - С. 48-73.

4. Канализация своими руками. Уровень грунтовых вод. - Режим доступа: http: //sistemakanalizatsii.ru/naruzhnaya/uroven-gruntovyix$\operatorname{vod7}$ (Дата обращения 20.08.2016)
5. Ковязин В.Ф., Любимцев А.В. Оценка влияния почвенно-грунтовых условий на породный состав производных лиственных лесов // Аграрный научный журнал. - 2013. - № 11. - С. 31-34.

6. Ковязин В.Ф., Мартынов А.Н. Состояние почв в урбоэкосистемах Санкт-Петербурга //Аграрный научный журнал. - 2014. - № 9. - С. 17-22.

7. Мониторинг почвенно-растительных ресурсов в экосистемах Санкт- Петербурга / В.Ф. Ковязин [и др.]; под ред. В.Ф. Ковязина. СПб., 2010. - 344 с.

8. Самофалова И.А., Дьяков В.П. Полевая учебная практика по географии почв с основами картографии: учеб. пособие. - М.; Пермь, 2010. - 16 с.

9. Koviazin V.F., Martynov A.N., Kuznetsov E.N. Soil conditions in the green areas of Saint Petersburg // ИВУЗ «Лесной журнал». - 2016. - № 4. - С. 9-18.

Ковязин Василий Фёдорович, д- $p$ биол. наук, проф. кафедры «Лесоводство», Санкт-Петербургский государственный лесотехнический университет имени С.М. Кирова. Россия.

Фам Тхи Куинь, магистрант 2-го курса, СанктПетербургский государственный лесотехнический университет имени С.М. Кирова. Россия.

Кан Ким Хынг, магистрант 2-го курса, СанктПетербургский государственный лесотехнический университет имени С.М. Кирова. Россия.

194021, г. Санкт-Петербург, Институтский пер., 5. Тел.: 8963307278.

Ключевые слова: парк «Сосновка»; профиль поверхности земли; уровень грунтовых вод; почвенный разрез; гранулометрический состав почвы.

\section{SOIL CONDITIONS IN THE PARK SOSNOVKA IN SAINT-PETERSBURG}

Kovyazin Vasiliy Fedorovich, Doctor of Biological Sciences, Professor of the chair "Forestry", Saint-Petersburg State Forestry University named after S.M. Kirov. Russia.

Pham Thi Quynh, Magistrandt of the 2-nd course, Saint-Petersburg State Forestry University named after S.M. Kirov. Russia.

Can Kim Hung, Magistrandt of the 2-nd course, SaintPetersburg State Forestry University named after S.M. Kirov. Russia.

Keywords: Park Sosnovka; soil profile; groundwater level; soil particle composition.
The article presents the results of many years' observations of soil conditions in the Park Sosnovka, which is located in the Vyborg district of St. Petersburg. Initially, pine plantation was predominant, but after changes in soil conditions small-leaved forest became predominant. They have been studied main factors determining soil conditions: groundwater level, morphology and granulometric composition. It was established that the groundwater level is correlated with the absolute mark of the territory regarding the Baltic Sea level. Subsoil water determines morphological structure of soil and its particle size. 